Ксенија Кончаревић

Универзитет у Београду

Филолошки факултет

Катедра за славистику

kkoncar@mts.rs
УДК 271.2-788:314.151.3-054.7(=161.1) https://doi.org/10.18485/slavistika.2021.25.1.5

Оригинални научни рад примљено 27.04.2021.

прихваћено за штампу 17.06.2021.

\title{
САВРЕМЕНИЦИ О РУСКОМ МОНАШТВУ У ЕГЗИЛУ*
}

Рад је посвећен разматрању сведочанстава савременика о утицају руских манастирских братстава и сестринстава у егзилу на обнову и развој српске духовности, са посебним освртом на значајне појединце - еминентне представнике руске духовне традиције - који су деловали у српским земљама као духовници и обновитељи манастира.

Кључне речи: Руска емиграција, руско монаштво у Србији и српским земљама, рускосрпске духовне везе, српска мемоаристика.

The paper considers the testimonies of contemporaries about the influence of Russian monastic brotherhoods and sisterhoods in exile on the renewal and development of Serbian spirituality, with a special reference to important individuals - eminent representatives of the Russian spiritual tradition - who acted in Serbian lands as spiritual fathers and monastery restorers.

Keywords: Russian emigration, Russian monasticism in Serbia and Serbian lands, RussianSerbian spiritual ties, Serbian memoirist writing.

Једну од најсветлијих страница деловања руске емиграције у српској и југословенској култури 20. века исписала су руска свештена лица - архијереји, свештеници, монаси пребегли на тле Краљевине Срба, Хрвата и Словенаца. Прецизних статистичких података о њиховом броју нема, вероватно не само због чињенице да су се многи од њих на нашим просторима затекли само у транзиту, него још више због чињенице да се нису морали пријављивати државним органима ради постављења на службу, а да су у окриљу Цркве стављани на располагање већем броју епархија, без вођења јединствене и централизоване евиденције о њиховом намештењу. М. Јовановић, према подацима статистичког одељења Државне комисије за прихват руских избеглица изведеним на узорку од 24.342 избеглице, наводи да је 1919-20. регистровано 84 (0,48\% од овог узорка) лица запослених у окриљу Цркве и 55 (0,24\%) оних који желе да се запосле у овој сфери (податак за 1921) (Јовановић 1996: 286). Православних свештеника, по истим подацима, регистровано је 1919-20. укупно $69(0,40 \%)$ и још 48 (0,21\%) који 1921. траже запослење (Јовановић 1996: 289). Ови подаци свакако нису комплетни и због чињенице да се њима не обухвата монаштво, с обзиром да се ова категорија не подводи ни под службенике Цркве, ни под радно активно становништво.

Руска црква у Краљевини СХС добија своје административно устројство, а од 1921, након одржавања Сверуског црквеног сабора у Сремским Карловцима

${ }^{*}$ Рад је израђен у оквиру пројекта “Српска теологија у XX веку: фундаменталне претпоставке теолошких дисциплина у европском контексту - историјска и савремена перспектива“, који финансијски подржава Министарство науке Републике Србије (евиденциони број пројекта ОИ 179078). 
и оснивања Архијерејског синода на челу са митрополитом Антонијем (Храповицким), постаје духовни стожер свих Руса у расејању. Оснивају се руске црквене општине, дижу руске богомоље, утемељују духовно-просветна братства, издају православне новине, часописи и књиге (в. Зейде 1988; Глигоријевић 1994; Глигориевич 1996; Цыпин 1997: 553-571). У годинама између два светска рата Руска црква показује се не само као кохезиона снага за све руске прогнанике, већ и као стожер руско-српског верског, културног и националног зближавања. Руска црква и њени верници добили су и од државних и од црквених органа снажну финансијску, материјалну и моралну подршку, али су уједно пружили и огроман подстицај оживљавању и развоју духовности код Срба. Утицај руских свештеника и монаха у нашој средини утолико је изразитији, уколико се имају на уму тешке околности у којима се Српска црква нашла у првим послератним годинама. Опустошене у оба балканска и у светском рату, српске земље остале су без многих свештених лица, док су манастири, посебно у Србији, Македонији, на Косову, као и парохије у Далмацији, Крајини и Босни, били крајње запуштени. Стога је, поред указивања сестринске помоћи и азила Сабору руских епископа и Светом архијерејском синоду Руске православне цркве у избеглиштву, Српска црква оберучке прихватила и велики број руских свештених лица - белог (мирског) свештенства и јеромонаха. Ступајући у службу Српске цркве, свештенство руског порекла упућивано је и у села и на удаљене парохије. Заједнички богослужбени језик и готово идентична богослужбена пракса омогућили су им лако прилагођавање у новој средини.

Руски монаси пристигли у таласу емиграције распоређени су у српске манастире. У некима су се формирале чисто руске обитељи (рецимо, братство манастира Миљкова на челу са јеромонахом Амвросијем (Кургановом) и двадесет петоро сабраће у манастиру Миљково, Браничевска епархија, Лесњенско сестринство са осамдесет монахиња у Хопову на Фрушкој Гори), а у већини су руски монаси и монахиње представљали језгро из кога ће се доцније развити нове монашке заједнице. Нарочиту пажњу заслужују случајеви постављења руских калуђера за старешине манастирских обитељи: рецимо, игуман Сергије постаће старешина манастира Тумане, а касније Манасије, архимандрит Кирил - манастира св. Прохора Пчињског, архимандрит, потоњи епископ сумски Митрофан - манастира Раковице и Дечана (он ће дуго година бити и управник Монашке школе у Дечанима), архимандрит Теодосије - такође дечански игуман, игуман Венијамин - настојатељ манастира Преподобног Наума Охридског на Охридском језеру (Радовић, Драгојевић 2009: 193-195). Захваљујући руским калуђерима обновљени су неки манастири у Србији који су били готово запустели, као што су Петковица код Шапца, Миљково на Морави и др. (Глигоријевић 1994: 54). У плејади великих српских духовника XX века - да поменемо само упокојене - било је оних који су непосредно формирани под утицајем руских калуђера: поред епископа Николаја (Велимировића) и архимандрита Јустина (Поповића), међу руске васпитанике можемо убројити архимандрита Тадеја (Штрбуловића), игумана манастира Витовница у Епархији браничевској (Арсенијевић 2004: 7-40), јеромонаха Макарија, духовника манастира Јовања у Овчарско-кабларској клисури, Епархија жичка (Димитријевић 2004: 118121), архимандрита Рафаила (Топаловића), игумана манастира Никоље у истој 
епархији (Димитријевић 2004: 122-126), игумана Преображењске обитељи код Овчар Бање Евстатија (Ракића) (Димитријевић 2004: 173-178) и многе друге.

О руским монасима скоро да нема историографских радова. Једно обимно дисертационо истраживање засновано на архивској грађи посвећено је улози руских духовника и игуманија у обнови и развоју српске женске монашке духовности (Грабеж 2010). Такође, једна студија, заснована на историографском материјалу, посвећена је личности и делу игуманије Катарине Јефимовске (Маркович 2018). Постоје монографска дела и дисертације у којима се у контексту опште културне и духовне климе 20 -их и 30-их година помиње и деловање руских манастира, истакнутних монаха и монахиња на тлу Србије и српских земаља, али не као примарни објекат истраживања (Арсеньев 1999; Пилиповић 2017; Суботић 1996). Малобројни су прилози у часописима и зборницима посвећени овој проблематици (Мрђеновић 2016; Радовић 1963; Радовић, Војиновић 1971). Отуда смо дошли на идеју да деловање истакнутих руских монаха и монахиња у егзилу прикажемо кроз мемоарску литературу и сведочанства савременика, снажно присутна у српској јавности и друштву у минулих сто година.

О стилу живљења у првим руским монашким обитељима на територији Србије сведоче успомене блаженопочившег архимандрита о. Тадеја (Штрбуловића), старешине манастира Витовница, који је као млад искушеник 1932. године доспео у манастир Миљково, где су живели и подвизавали се руски калуђери из Валаамске обитељи, који су, нашавши се у канонском нејединству са Финском православном црквом под чију је јурисдикцију доспела „Северна Света Гора“, између 1925. и 1927. били принуђени да напусте свој манастир. Они су, предвођени схиархимандритом Амвросијем (Кургановом), духовним чедом преподобног Амвросија Оптинског, овамо пренели исихастички дух који је Валаам примио од Оптине пустиње (Цыпин 1997: 217-218). Архимандрит Тадеј овако дочарава лик свога духовног оца: „Из о. Амвросија је избијала невероватна и чиста љубав: он је од стараца из Оптине пустиње примио оно што је најбоље - љубав, те се никада ни на једнога монаха или послушника није разљутио, нити је иједну преку реч икоме рекао. Трпео је много, а све је праштао. Све бриге и проблеме предавао је Господу и Њему Јединоме се јадао. Трудио се да ту особину својим примером пренесе и на братију, и многи су од њега научили како да негују ту свеобухватну и бестрасну љубав у свакодневном животу“ (Арсенијевић 2004: 13). Сећа се отац Тадеј како је игуман „долазио у цркву на богослужења увек први и стао би за игумански стол (стасидију, прим. наша). Видело се да је просто сатрвен бригама, али никоме ништа да каже, све је полагао на Господа. Никада никога није казнио. Никоме чак ни лошу мисао није упутио, ни преки поглед, нити било шта. Свакога је љубио онаквог какав јесте и молио се Богу да га Он просветли. Својим примером живљења је највише поучавао и настојао да свакога преко тога примера доведе на пут спасења“ (Арсенијевић 2004: 14). Искушеник Томислав, „Томушка“, како су га називала руска сабраћа, чим је прекорачио праг свете обитељи, добио је бројаницу у руке и поуку како да се моли умно-срдачном (Исусовом) молитвом. Наравно, нису га мимоишла ни физичка послушања, и премда, по властитом признању, у њиховом обављању није био нарочито успешан (једном су му лопови покрали читав ви- 
ноград, други пут су му овце одлутале и направиле штету на суседном имању), нико га никада није ни изгрдио, нити прекорио због штета које је обитељи нанео својом непажњом (Арсенијевић 2004: 14-15). У Миљкову је Томислав научио и руски језик, што му је омогућило да почне студиозно да чита, а каткада и преводи Свете Оце који су на руски били преведени са грчког и сиријског језика (сачувани су рукописи његових превода Речи св. Исака Сиријског и неких дела св. Симеона Новог Богослова) (Никчевић 2015: 381). Предавши се свим срцем и свом душом духовном руковођењу старца Амвросија, живећи по захтевном валаамском (оптинско-светогорском) типику, испуњавајући строго и захтевно молитвено правило, свакодневно присуствујући дугим службама (пун дневни круг богослужења, уз редовно служење Божанствене Литургије), строго постећи, млади Томислав Штрбуловић разгорео се у овом „српском Валааму“ огњем љубави Божије и постепено узрастао у једног од највећих савремених српских духовника (подробно о Миљковском манастиру и његовим духовницима у сећањима оца Тадеја в. у: Никчевић 2015: 379-386). Слично искуство имали су и многи други српски искушеници и монаси који су живели међу руским калуђерима или под управом руских игумана.

Један од руских стараца који су оставили дубок траг у српској средини био је архимандрит Теодосије (Мељник), потоњи игуман Високих Дечана. Рођен је 1890. на југу Русије. Још као младић отишао је у Кијево-Печерску лавру као искушеник. Пошто није био замонашен, мобилисан је 1914. године и рат провео као артиљерац, показавши изузетну храброст, за шта је три пута награђен крстом Светог Георгија, највишим војним одликовањем царске Русије. Вративши се у Лавру, постаје келејник митрополита Антонија Храповицког, и ту дужност испуњавао је пуних 18 година, до митрополитовог упокојења августа 1936. Одмах је прешао у јурисдикцију Српске цркве. За овај манастир везано је последњих 20 година његовог живота. Архимандрит Алексеј Богићевић, постриженик манастира Дечани и један од најистакнутијих данашњих српских духовника (иначе игуман манастира Св. Луке у Бошњанима, Епархија крушевачка), у својим мемоарима пише: „Сећање на њега није избледело... Старешина у цркви, обасјан сунчевим зрацима, који се сливају са прозора и као златни слап преплављују амвон и величанственог старца Теодосија. Причали су људи да нису лепшу појаву видели, нити је могла да се замисли, него што је био достојанствени архимандрит Теодосије, кад недељом после службе у белој мантији крене да обилази имање. Изгледао је као неки витез из старине. Памтим његове руке, велике, снажне и нежне шаке које су мирисале на тамјан и бомбоне, којима је сву децу даривао“. И даље: „Када би појао дивни кондак „В молитвах неусипајушчују“ старо-кијевским напевом, што га је подсећало на младе монашке дане у његовој Кијево-Печерској лаври, није могао да задржи сузе..."“(Богићевић 2014: 77).

Игуман Теодосије суочио се и са великим искушењима када је почетком 50их година нова власт све одузела: ризницу, сву земљу, шуме, њиве и винограде, краве, свиње, кошеве пуне кукуруза и пшенице, чак кључ од цркве, чиме су монаси онемогућени да служе у храму, па су служили у малој капелици у конаку. „Вероватно су мислили да ће тако отерати монахе, али се архимандрит Теодосије није дао. Сачувао је братство, молио и кумио све. Написао је десетине 
молби и преклињања, све док му кључ од цркве није враћен“ (Богићевић 2014: 143). Баћушка Теодосије био је омиљен у народу, сви верници из Метохије називали су га просто „старешина“ и кад су сазнали у каквој се оскудици братија нашла - „ни шака кукурузног брашна за проју није могла да се сакупи, ни капи уља за кандило није било - добре душе из Дечана и Лоћана су у манастир кришом доносиле уље, брашно и нешто за јело“" (Богићевић 2014: 144).

Архимандрит Алексеј описује и искушење које је игуман Теодосије доживео када је неодољиво пожелео да види лице Светог краља Стефана Дечанског, па је отворио кивот, иако није било време за пресвлачење моштију, нити је прочитао посебне молитве које се изговарају у таквим приликама: „Како је почео да скида покровац, тако је почео да га преплављује ужасан страх. Њега, неустрашивог артиљерца, који је кроз многе смртне опасности у животу прошао и никада се ничега, осим Бога, није бојао, обузео је ужас од кога слабији с ума силазе. Избезумљен од страха потрчао је према вратима, али није могао да помери греду, ни да отвори врата. Лупао је и дозивао док неко од монаха није дошао и откључао врата која могу споља да се отворе. Неустрашиви архимандрит је осетио шта значи страх Божији и гнев светитеља““ (Богићевић 2014: 85).

Нису само старешине манастира биле описане у мемоарској литератури, него и неки други питорескни ликови руских калуђера. Један од њих био је и старац Полихроније, који се подвизавао у царској лаври Високи Дечани. Био је потомак великих кнезова Романових, у младости постриженик Валаамског манастира. Архимандрит Алексеј Богићевић сећа се његовог лика, дивног појања, ревносног обављања послушања манастирског пчелара: „Био је у позамашним годинама, бео косом и ликом, тих, неприметан, са лицем као да је сишао са фреске неког древног руског храма. Имао је послушање да чита и пева канон на јутрењу, и радио је то са неким посебним надахнућем, за једног старца необично јаким и звонким гласом, са руским северним нагласком. Он је бринуо о кошницама и већи део слободног времена вазда је нешто петљао око њих. Када бисте му изненада пришли, чули бисте да стално изговара речи неке молитве, или разговара са својим „питомицама“. Муке су настајале када је долазило време да се мед врца. Он никако није допуштао да се мед „отима“ од пчела! Знао је увек, онако светачки тих, тада чак да узме виле и стане пред кошнице да их брани! Наравно, никакво насиље није долазило у обзир. Мудри игуман Тадеј измислио би онда неко заиста „свеноћно“ бденије и одредио њега да поје и чита, па би те ноћи кошнице биле испражњене! Када би то ујутро видео, старац би истински плакао и неколико дана избегавао осталу братију“ (Богићевић 2014: 81).

Како сведочи архимандрит Алексеј, управо је старац Полихроније очувао тајну где су закопана звона што су их руски монаси из келије Св. Јована Златоуста на Светој Гори донели када су прешли у Дечане. Звона су нестала 1914. године. Веровало се да су их однели припадници аустроугарске војске, као што су односили сва звона из српских цркава и манастира и претапали их да од њих лију топове. Међутим, руски монаси су умотали звона у пртену (кудељну) тканину, претходно добро натопљену катраном, и закопали их негде у околини. Тајну дечанских звона старац Полихроније поверио је игуману Макарију. „Звона су и данас тамо. Многи се сећају да су стари Дечанци и сви Метохијци, који су памтили чудесни пој дечанских звона, после Другог светског рата ша- 
патом препричавали да им се чинило да сами анђели с неба силазе кад зазвоне. Тако и треба да остане, док не дође време да просија оно што је у земљу закопано“, закључује своје казивање архимандрит Алексеј (Богићевић 2014: 163-164). Иначе, баћушка Теодосије сачувао је и игумански штап који је са Свете Горе донео архимандрит Кирило, настојатељ обитељи Св. Јована Златоуста. „Био је необичан, али леп. Ко зна колико је игумана уз помоћ тог штапа савладавало светогорске стазе и богазе. Кирилов штап наследио је игуман дечански Теодосије, а после Теодосијеве смрти, архимандрит Макарије, потом је припао Јустину“, а овај га је поклонио тадашњем владики банатском Амфилохију, потоњем митрополиту црногорско-приморском, који је касније рекао: „Дарујући ми овај архимандритски штап, ви као да сте предвидели да ће ми добро доћи по црногорским врлетима“" (Богићевић 2014: 165).

Дирљиво је и сећање архимандрита Алексеја на девичког духовника о. Димитрија, посебно на његову блажену кончину:

„Отац Димитрије стално је говорио како ће он за Васкрс да иде у Русију, у Русију па у Русију. И тако годинама, свим срцем је желео да се врати у Русију, али није могао, био је емигрант. Једне године, на Васкрс ујутро, после Литургије, повукао се у келију. Поподне су га нашли. Упокојио се. Тако је Димитрије Рус, заиста, на Васкрс отишао у Русију. У своју вољену, Небеску Русију“ (Богићевић 2014: 165).

Руски женски манастири на Фрушкој Гори - Хопово и Кувеждин - оставили су снажан утисак на побожне српске девојке. Богочежњиве младе душе долазиле су са свих страна на службе у Хопово, посебно на свеноћна бдења, из Мачве и из удаљених војвођанских села, пешачећи и по шездесет километара. Међу њима су биле и наше најистакнутије будуће игуманије - мати Аполинарија из манастира Крушедол, мати Јелена Јокић, игуманија манастира Драче, мати Ана Аџић, која ће се наћи на челу манастира Враћевшница, и друге. Схимонахиња Марија из Србобрана, која је међу првим Српкињама ступила у Хопово, сећа се како је први пут доживела свеноћно бдење пред празник Лесњенске иконе Мајке Божије: „Три хора, сто монахујућих на трепетној молитви, служи баћушка Алексеј, духовник манастира, велики молитвеник и као мирски свештеник, и јеросхимонах Никандар“. Деветнаестогодишња Марија је одмах донела одлуку да се замонаши, али је због недостатака простора нису одмах примили, него после извесног времена, заједно са још једном девојком, потоњом монахињом Исидором, под условом да три године станују на тавану. Касније је мати о томе приповедала: „Да су ми рекли на оџак - на оџак! Ја бих то са вером примила“ (Радовић, Драгојевић 2009: 194-195). Упечатљива су и сведочанства Наде (потоње игуманије Ане) Аџић, кћерке чувеног педагога Сретена Аџића, о њеним првим одласцима у манастир Хопово, упознавању са игуманијом Екатерином, разговорима са искушеницом Лидијом (Дохторовом, у раси и малој схими Диодором, у великој схими Маријом) и монахињом Сидонијом о духовном животу, првој исповести којој је приступила под кровом ове свештене обитељи а за коју ју је припремала сестра Лидија (,,то није био српски обичај“, објашњава мати Ана у својим мемоарима), о благољепним службама које је овде доживела, а све је то утицало на њено будуће опредељење за монашки пут, за који је добила благослов свога духовног оца, епископа охридског Николаја 
Велимировића. „Васкрсло ме је Хопово! И тијелом и душом осјећам благодат и благослов Хопова!“”, сећа се мати Ана. „Отац Алексеј, ‘баћушка', је тамошњи свештеник, Рус. Какав је то диван човјек <...>! На његовој служби стојиш пуна два сата и не осјетиш да си стајао, могло би се стајати још док је он ту и моли се. Кроз службу коју он свом душом одаје Богу, осјећаш његову личну потребу да служи Богу. Он кад служи, он је само са душом својом. Не чини дужност по дужности, већ по потреби душе своје. И то смирено, без помпе, без заноса <... . Сестра Лидија учинила је на мене велики утисак. Она је сасвим света, и канда се стално моли и за вријеме разговора с ким, увијек је душом у молитви. Још врло млада (26-28 година), доста мала, руменог, округластог, помало пјегавог лица, плавих крупних очију. Чудне очи. У њима се заиста види небо. Она, кад прича, скоро увијек управља очи ка небу, а кад њој ја причам или кад ми она поставља питања гледа тако дубоко у мене, да ми се чини да ће сагледати у мени оно што још нисам казала, да ће сагледати мене цијелу“ (Аџић 2003: 42-45).

Друга женска монашка обитељ о којој је остало доста сведочанстава био је Кувеждин, такође на Фрушкој Гори, где је 1930. године било осамнаест расофорних монахиња Рускиња, четрнаест Српкиња искушеница и четири српске монахиње (Петковић 1930: 7). Одговорне манастирске дужности, изузев дужности игуманије (мати Меланија Кривокућин), вршиле су искључиво Рускиње: намесница је била монахиња Серафима (Томска), надзорница мати Александра (Волкова), уставшчица мати Јелисавета (Колобзина), пономарка мати Вера (Лукјањук), економка мати Евгенија (Вишњевска), библиотекарка мати Серафима (Томска), трпезарка мати Ксенија (Морозјук), болничарка мати Агнија (Слаута) (списак монахиња и искушеница ове обитељи са основним биографским подацима в. у: Радовић, Драгојевић 2009: 117-119).

Живот и рад сестара у Кувеждину, по сведочењу протојереја Саве Петковића, професора Карловачке богословије, био је регулисан властитим дисциплинарним типиком, који је у неким аспектима послужио и као основа за доношење првог сродног нормативног документа у српској средини - Устава женских манастира у Српској православној иркви из 1927. Све сестре биле су заузете на првом месту молитвом у храму и испуњавањем келијног правила, а затим послушањима. Постојале су две врсте послушања - стална и „чредна“ (по „дежурствима“ - од недеље ујутро до суботе увече, дакле, на седам дана). Стална послушања подразумевала су извесне дужности у управљању манастиром и газдинством (намесница, надзорница, уставшчица, пономарка, економка, библиотекарка, трпезарка, болничарка, баштованка, краварка, живинарка), као и у свакодневним активностима (појање у храму, израђивање икона, митри, одежди, крстова, бројаница, израда свећа, печење просфора, рад у кухињи и манастирској пекари). Чредна послушања односила су се на читање одломака из богослужбених књига, акатиста, јутарњег, вечерњег молитвеног правила и полуноћнице, послуживање у трпезарији, у келијама игуманије и духовника, у гостињским собама, спремање сестринских соба. Манастирски дан отпочињао је у четири сата ујутро лети, а зими у пет, читањем полуноћнице, јутарњег правила и часова, настављао се доручком и послушањима, у подне се ручало уз читање житија Светога који се прославља тога дана, следила су послушања до вечерње службе у шест сати (зими у пет), вечера, читање акатиста и молитава 
пред спавање, а на починак се полазило у 9 (зими у 8 сати). У поподневним и вечерњим часовима, посебно зими, старије монахиње поучавале су искушенице у појању и читању молитава на црквенословенском језику, а мати Серафима (Томска) држала је сестрама и систематска предавања из разних области богословља. Средом, петком и суботом служила се литургија у 7 сати ујутро, а недељом и празницима у 10 сати. Недељом и о празницима сестре су биле слободне од послушања, шетале су по шуми, одмарале се у келијама, читале књиге. Прота Сава Петковић истиче да је манастир био јединствен у српској средини по томе што се у њему практиковао богослужбени устав „неусипајушчих“. У капели на западном делу конака, посвећеној Покрову Пресвете Богородице, двадесет четири сата монахиње су се непрестано смењивале на сваких сат времена, читајући Псалтир са последовањем. Првих дванаест сати помињана су имена живих, а других дванаест сати упокојених. Током ноћи, од десет увече до три ујутро, смењивале су се само старије монахиње, малосхимнице (Петковић 1930: 20-24).

Од великих руских монахиња посебну пажњу међу савременицима изазвала је Игуманија Екатерина (Јефимовска), која је деловала у манастиру Ново Хопово на Фрушкој Гори, где је новембра 1920. године смештено осамдесетак монахиња из манастира Пресвете Богородице у Љесни (бивша Холмсковаршавска епархија). Са чудотворном иконом Пресвете Богородице Лесњенске у рукама монахиње су, спасавајући своје животе, у Србију стигле из Бесарабије (о историјату манастира в.: Леушинская 1992; Черкасов-Георгиевский 2003). Мати Екатерина, иначе, била је личност великог интелектуалног и духовног формата и несвакидашњег животног искуства: у свету грофица Евгенија Борисовна, дипломирала је на Московском универзитету, објављивала литерарне радове, лично се познавала са И. С. Тургењевом и В. Соловјовом, а у манастир је ступила са 33 године са благословом архиепископа варшавског Леонтија. Имала је духовно руковођење од знаменитог кронштатског свештеника Јована Иљича Сергијева (касније канонизованог као св. праведни Јован Кронштатски). У српској средини мати Екатерина почиње да окупља око себе и свога сестринства не само руске емигранте, него и српску интелигенцију. На њену иницијативу основан је Руско-српски кружок у Београду као прва организација овакве врсте у Србији, чији чланови постају истакнути руски и српски хришћански интелектуалци - архимандрит Јустин Поповић, Десанка Максимовић, Кипријан Керн, Николај Афанасјев, Марија, Софија и Николај Зернов, Велибор Глигорић, Душан К. Петровић и други (о деловању кружока податке пружају, између осталог, мемоари игуманије Ане Аџић, која се у њега учланила као посестрима руске породице Зернов - исп. Аџић 2003:108). У дневничком запису од 17. октобра 1924. побожна девојка Нада Аџић сведочи: „Игуманија манастира Хопова, мати Катарина, врло је оштроумна, њено лице је живахно, оштрих црта, малко загонетно. Стара је врло, доста ситна, жива, без ноге и зато иде на штакама. Чујем да је велики богослов и књижевник, са великим новим идејама, које су биле на путу остварења када је букнула револуција“ (Аџић 2003: 42). Монахиња Агатија највише ју је запамтила по њеном необичном смирењу и скромности, по томе што се ,увијек и свуда трудила да буде незапажена: 'Хришћанин би увијек требало да се задовољи посљедњим мјестом', 
вољела је да каже“. Ова саподвижница игуманије Екатерине живо се сећа и њених последњих тренутака октобра 1925. године: „Када су је љекари питали како се осјећа, одговорила је: 'Вријеме је да одбацим овај стари капут, сасвим је похабан'. До краја мјесеца било је очигледно да матушка умире. Отвориле су joj се каверне на плућима. <..> Замолила је, тешко говорећи, да сви њени списи буду предати Зендеру у Париз“. Молила се да престане да избацује крв, како би могла да се причести. „Баћушка ју је причестио у миру, примила је Свето Причешће навече уочи своје блажене кончине, а да се није ни закашљала. И била је удостојена виђења Горњег Јерусалима“". И пошто је свештеник очитао Канон на исход душе, матушка је благословила све сестре, а на крају је замолила мати Анатолију да је осени знаком крста „и врло тихо и мирно је уснула у Господу“ (Агатија 1977: 56-57). Ава Јустин забележио је о овој истакнутој игуманији, коју су с правом називали „апостолом српског женског монаштва“, и следеће редове: „Живела је на земљи правећи лествице између овог и оног света, између душе своје и чудесног Господа Христа <..>. Преображеном душом преобразила је и тело: узлетела је до најтананијих, до најделикатнијих философско-религиозних проблема, који се једино могу решити облагодаћеним умом, облагодаћеним срцем, облагодаћеним телом, облагодаћеном душом. Поражавала ме је дубином својих опажања, осећао сам она се научила царству небескоме, и као добра домаћица износи из клијети срца свог нове мисли, нова осећања, нову мудрост. <... Зато је могла љубављу и благошћу робити душе на познање Христа“. А њен психолошки профил архимандрит Јустин убедљиво је дочарао речима: „У њеном присуству осећао си да је човек више душа него тело; она је умела да скрати растојање између њене душе и твоје. Она је имала сталан осмех, не туђ, не позајмљен, већ њен сопствени милостиви, благи осмех. Гледајући њу, ја сам говорио себи: да, ваистину, она је горку тајну живота учинила слатком“ (Поповић 1925: 545-546).

Међу знаменитим монахињама руског порекла које су деловале у српској средини пажњу и сећање савременика заслужила је и игуманија Диодора (у свету Лидија Николајевна Дохторова, 1896-1978), која је постала искушеница у Хопову, замонашена 1925. од епископа нишког Доситеја и постављена 1930. за игуманију манастира Светог Димитрија у Дивљанима код Беле Паланке (Епархија нишка). Ова изузетна подвижница, која је завршила Историјскофилолошки факултет Московског универзитета (о њеном животу детаљније в. y: Динев 2006: 39-91), својим узвишеним аскетским подвигом (спавала је на поду, највише по четири сата дневно, двадесет година се хранила само хлебом, а неколико година само пресним поврћем, четири седмице Великог и једну седмицу Успењског поста проводила је без хране и пића, изучавала је дела светих Отаца, посебно Макарија Великог, Григорија Богослова, Исака Сирина и Симеона Новог Богослова), саможртвеним примером служења Цркви и одличним устројењем манастирског поретка многе је девојке и жене привукла у обитељ, тако да већ 1937. године у манастиру који јој је поверен живи четрдесет сестара. О атмосфери која је тамо владала налазимо овакав запис: „Живот калуђерица у овом манастиру сличан је животу светогорских калуђера. Апсолутна послушност доследно је заступљена. Поред обавезног учешћа на свим богослужењима, калуђерице саме обрађују манастирско имање. Радови и 
занимања сестара веома су разнолики. Осим старог боголепног црквеног реда, певања и читања, сестре још раде и у радионицама, од којих имају следеће: иконописна, радионица за везење златом, везење црквеног и обичног одела, за обично ткање, за ручне радове, за штрикање и израду свећа, и обуће <...>. Пријатно је бити у Дивљанском манастиру, макар и на кратко време. Савршен ред, примерена чистоћа, непрекидна молитва, послушност, смерност сестара и све остало што човека духовно уздиже, да у моментима заборави на све што је земаљско и мисли само на небеско. Ово духовно расположење наступа нарочито за време Свете Литургије када се појави хор од 40 сестара, које обучене у црнини и у дугим мантијама, испијена и бледа лица, прослављају Бога својом дивном песмом“ (Спиридоновић Пелех 1937: 16-17). Под својом управом имала је још тридесет две сестре у манастирима Светог великомученика Георгија (Темска) и Светог Стефана (Липовац). У Србији је основала и обновила седам манастира и била духовна мајка многим српским монахињама. У повереним јој обитељима примењивала је дисциплинарни типик преподобног Кирила Белојезерског, написан под утицајем устава Лавре св. Саве Освећеног и најстаријег руског општежитељног устава преподобног Теодосија Печерског. Устајало се у три ујутро, рана служба је отпочињала полуноћницом и свршавала свакодневном Литургијом, јело се два пута дневно, а после вечерње све монахиње су матушки исповедале помисли (Диниев 2006: 211-213). Мати се молила за сестре, носила бреме сваке од њих, а када би имала потребе да казни неку монахињу, налагала је на себе епитимију и обитавала без хране три дана. Сестре су волеле своју духовну мајку. Када су једном добиле благослов да направе два манастира, нису хтеле да се раздвајају. Крајем 30-их година целокупно сестринство прелази у Македонију, у манастир Свете Пречисте код Кичева, где остају до 1945, када се настањују у Благовештењском манастиру у Страгару, који је у то време припадао Архиепископији београдско-карловачкој (Динев 2006: 81-84). Овде је мати Диодора примила велику схиму са именом Марија. Али њен молитвени спокој прекинут је наредбом југословенских власти да, због сукоба са совјетским руководством после Резолуције Информбироа, сви Руси који бораве у нашој земљи морају примити и југословенско држављанство, а додатни услов за клирике био је и да се морају одрећи јурисдикције Московске Патријаршије. Схиигуманији Марији овај услов био је неприхватљив, и зато она одлази најпре у Албанију (1950), а затим у Бугарску, у манастир преподобне Параскеве недалеко од Софије, где 1954. уводи скитски устав Нила Сорског и где ће се у дубокој старости и упокојити (1978).

Руско монаштво, по једнодушној оцени савременика, пружило је снажан импулс обнови духовности - како монашке, тако и лаичке - у српском народу током XX века. Српски мемоаристи и духовни писци највише се задржавају на следећим моментима: устројавање монашког општежића на далеко вишем нивоу од онога који је затечен у домаћој средини; обнављање институције женског монаштва; унапређење и интензивирање богослужбене праксе; пресађивање исихастичких традиција најбољих руских обитељи у нашу средину; неговање црквене културе и уметности, посебно појања и иконописања; мисионарски рад међу народом; обнова манастирских храмова, здања, економија, очување реликвија; харитативна делатност; сведочење, како монашких заједница у цели- 
ни, тако и манастирских духовника и игуманија, највишег, есхатолошког смисла нашег постојања, преображавање емпиријске реалности агапичним молитвено-делатним, литургијско-подвижничким оприсутњењем Есхатона.

\section{Цитирана литература}

Арсеньев, Алексей. У излучины Дуная: Очерки жизни и деятельности русских в Новом Саду. Москва: Русский путь, 1999.

[Arsen'yev, Aleksey. U izluchiny Dunaya: Ocherki zhizni i deyatel'nosti russkikh v Novom Sadu. Moskva: Russkiy put', 1999.]

Глигориевич, Бранислав. „Русская православная церковь в период между двумя мировыми войнами“. [В сб.:] А. Арсеньев, М. Сибинович [et al.] (ред.), Русская эмиграция в Югославии. Москва: Индрик, 1996, 109-117.

[Gligoriyevich, Branislav. «Russkaya pravoslavnaya tserkov' v period mezhdu dvumya mirovymi voynami». [V sb .:] A. Arsen’yev, M. Sibinovich [i dr.] (Red.), Russkaya emigratsiya v Yugoslavii. Moskva: Indrik, 1996, 109-117.]

Глигоријевић, Бранислав. „Руска православна црква у Југославији између два рата“. [У зб.:] М. Сибиновић (уред.), Руска емиграција у српској култури XX века. Т. I. Београд, 1994, стр. 52-59.

[Gligorijević, Branislav. „Ruska pravoslavna crkva u Jugoslaviji između dva rata“. [U zb.:] M. Sibinović (ured.), Ruska emigracija u srpskoj kulturi XX veka. T. I. Beograd, 1994, str. 52-59.]

Грабеж, Дамаскин. Влияние русского монашества первой эмиграционной волны на духовную жизнь в Сербии 20-30 годов XX века. Автореферат диссертации на соискание ученой степени кандидата богословия. Кафедра Церковной истории Московской духовной академии. Сергиев Посад: Лавра, Академия, 2010.

[Grabezh, Damaskin. Vliyaniye russkogo monashestva pervoy emigratsionnoy volny na dukhovnuyu zhizn' v Serbii 20-30 godov XX veka. Avtoreferat dissertatsii na soiskaniye uchenoy stepeni kandidata bogosloviya. Kafedra Tserkovnoy istorii Moskovskoy dukhovnoy akademii. Sergiyev Posad: Lavra, Akademiya, 2010.]

Зейде, Георгий. „Русская Православная Церковь Заграницей“. [В сб.:] Юбилейный сборник в память 1000-летия крещения Руси (988-1988). Джорданвилль: СвятоТроицкий монастырь, 1988, 323-350.

[Zeyde, Georgiy. „Russkaya Pravoslavnaya Tserkov’ Zagranitsey“. [V sb .:] Yubileynyy sbornik v pamyat' 1000-letiya kreshcheniya Rusi (988-1988). Dzhordanvill’: SvyatoTroitskiy monastyr', 1988, 323-350.]

Јовановић, Мирослав. Досељавање руских избеглица у Краљевину СХС 1919-1924. Књига I. Београд: Стубови културе, 1996.

[Jovanović, Miroslav. Doseljavanje ruskih izbeglica u Kraljevinu SHS 1919-1924. Knjiga I. Beograd: Stubovi kulture, 1996.]

Леушинская, Таисия. Свято-Богородичный монастырь во имя Леснинской иконы Божией Матери. Русское Православное женское монашество XVIII - XX вв. Сергиев Посад: Троице-Сергиева Лавра, 1992.

[Leushinskaya, Taisiya. Svyato-Bogorodichnyy monastyr' vo imya Lesninskoy ikony Bozhiyey Materi. Russkoye Pravoslavnoye zhenskoye monashestvo XVIII - XX vv. 
Sergiyev Posad: Troitse-Sergiyeva Lavra, 1992.]

Маркович, Деян. „Игумения Екатерина - обновительница сербского женского монашества“. Црквене студије 15, 2018: 609-623.

[Markovich, Deyan. „Igumeniya Yekaterina - obnovitel'nitsa serbskogo zhenskogo monashestva“. Tsrkvene studiǰe 15, 2018: 609-623.]

Петковић, Сава. Руски женски манастир у Љесни. Братство: 9, 1930: 141-144.

[Petković, Sava. Ruski ženski manastir u Ljesni. Bratstvo: 9, 1930: 141-144.]

Пилиповић, Радован. Српска православна црква, Руска православна загранична црква, Московска патријаршија (1920-1940) - узајамне везе, утицаји и односи. Докторска дисертација. Београд: Филозофски факултет, Одељење за историју, 2017. (дактилографисани рукопис)

[Pilipović, Radovan. Srpska pravoslavna crkva, Ruska pravoslavna zagranična crkva, Moskovska patrijaršija (1920-1940) - uzajamne veze, uticaji i odnosi. Doktorska disertacija. Beograd: Filozofski fakultet, Odeljenje za istoriju, 2017. (daktilografisani rukopis)]

Радовић, Ристо. Историја српског женског монаштва, Београд: Гласник СПЦ, 1, 1963: 20-27.

[Radović, Risto. Istorija srpskog ženskog monaštva, Beograd: Glasnik SPC, 1, 1963: 20-27.]

Радовић, Амфилохије и Хризостом Војиновић. „Обнова и развој нашег женског монаштва“. [У зб.:] Митровић, В. (уред.). Српска Православна Црква 1920-1970. Споменица о 50-годишњици васпостављања Српске Патријаршије. Београд, 1971, 333-343.

[Radović, Amfilohije i Hrizostom Vojinović. „Obnova i razvoj našeg ženskog monaštva““. [U zb.:] Mitrović, V. (ured.). Srpska Pravoslavna Crkva 1920-1970. Spomenica o 50-godišnjici vaspostavljanja Srpske Patrijaršije. Beograd, 1971, 333-343.]

Радовић, Амфилохије и Амфилохија Драгојевић. Подвижнице Христове љубави. Женско монаштво у историји Цркве са посебним освртом на подвижнице Христове љубави код православних Срба. Поуке преподобних матера и подвижница. Цетиње: Светигора, Беране: Свевиђе, 2009.

[Radović, Amfilohije i Amfilohija Dragojević. Podvižnice Hristove ljubavi. Žensko monaštvo u istoriji Crkve sa posebnim osvrtom na podvižnice Hristove ljubavi kod pravoslavnih Srba. Pouke prepodobnih matera i podvižnica. Cetinje: Svetigora, Berane: Sveviđe, 2009.]

Суботић, Драган. Епископ Николај и православни богомољачки покрет. Нова Искра, Београд, 1996.

[Subotić, Dragan. Episkop Nikolaj i pravoslavni bogomoljački pokret. Nova Iskra, Beograd, 1996.]

Цыпин, Владислав. История Русской Церкви 1917-1997. Москва: ЦНЦ „Православная энциклопедия“, 1997.

[Tsypin, Vladislav. Istoriya Russkoy Tserkvi 1917-1997. Moskva: TSNTS «Pravoslavnaya entsiklopediya», 1997.]

Черкасов-Георгиевский, Владимир. Русский храм на чужбине. Москва: «Паломникъ», 2003.

[Cherkasov-Georgiyevskiy, Vladimir. Russkiy khram na chuzhbine. Moskva: «Palomnik», 2003.] 


\section{Извори}

Арсенијевић, Матеј. Старац Тадеј Витовнички: Мир и радост у Духу Светом. Поуке, беседе, разговори. Београд: ПМШ „Св. Александар Невски“, 2004.

[Arsenijević, Matej. Starac Tadej Vitovnički: Mir i radost u Duhu Svetom. Pouke, besede, razgovori. Beograd: PMŠ „Sv. Aleksandar Nevski“, 2004.]

Аџић, Ана. Одабрани записи и преписка. Прир. Мила Стојнић. Манастир Враћевшница, 2003.

[Adžić, Ana. Odabrani zapisi i prepiska. Prir. Mila Stojnić. Manastir Vraćevšnica, 2003.] Богићевић, Алексеј. Дечанске и друге приче. Бошњане: Манастир Св. Луке, 2014.

[Bogićević, Aleksej. Dečanske i druge priče. Bošnjane: Manastir Sv. Luke, 2014.]

Динев, Гаврило. Схиигуманија Марија Дохторова: животопис, писма. Земун: Ризница, Биоче: Манастир Дуга, 2006.

[Dinev, Gavrilo. Shiigumanija Marija Dohtorova: životopis, pisma. Zemun: Riznica, Bioče: Manastir Duga, 2006.]

Димитријевић, Владимир. Без Бога ни преко прага. Српски духовници XX века. Житија и поуке. Београд: ПМШ „Св. Александар Невски“, 2004.

[Dimitrijević, Vladimir. Bez Boga ni preko praga. Srpski duhovnici HH veka. Žitija i pouke. Beograd: PMŠ „Sv. Aleksandar Nevski“, 2004.]

Никчевић, Весна. Српски духовни луг. Подвижници XX века. Београд: ПМШ „Св. Александар Невски“, 2015.

[Nikčević, Vesna. Srpski duhovni lug. Podvižnici XX veka. Beograd: PMŠ „Sv. Aleksandar Nevski“, 2015.]

Петковић, Сава. Српски женски манастир Кувеждин. Сремски Карловци: Српска манастирска штампарија, 1930.

[Petković, Sava. Srpski ženski manastir Kuveždin. Sremski Karlovci: Srpska manastirska štamparija, 1930.]

Поповић, Јустин. „О њој - необичној Рускињи међу нама обичнима“. Хришћански живот, IV, 12, 1925: 543-547.

[Popović, Justin. „O njoj - neobičnoj Ruskinji među nama običnima“. Hrišćanski život, IV, 12, 1925: 543-547.]

Спиридоновић Пелех, Михаил. Православни манастири Нишке епархије. Ниш: Глас Епархије нишке, 1937.

[Spiridonović Peleh, Mihail. Pravoslavni manastiri Niške eparhije. Niš: Glas Eparhije niške, 1937.] 
Ксения Кончаревич

\title{
РУССКОЕ ЭМИГРАНТСКОЕ МОНАШЕСТВО В ВОСПОМИНАНИЯХ СОВРЕМЕННИКОВ
}

\begin{abstract}
Резюме
В статье рассматриваются свидетельства современников о русских монастырских обителях, знаменитых духовниках и игумениях, оказавшихся после Октябрьской революции в Сербии и сербских областях. Автор приходит к выводу о том, что современники высоко ценили сильнейшее воздействие русского монашества на возрождение не только монашеской, но и мирской духовности в сербских землях в период между двумя мировыми войнами, проявившееся особенно в повторном учреждении сербского женского монашества, распространении церковной культуры и искусства, миссионерской и благотворительной работе, восстановлении храмов и монастырских зданий, насаждении русских дисциплинарных уставов в сербских обителях, духовном формировании будущих знаменитых монастыреначальников сербского происхождения и поощрении развития монашеских кадров.
\end{abstract}

